\title{
'Invaders of a peaceful country': Aborigines and explorers on the lower Victoria River, Northern Territory
}

\author{
Darrell Lewis
}

\section{Introduction}

The Victoria River lies in the northwest of the Northern Territory, within the tropical monsoon belt. Rising in the sand plains of the desert fringe, it winds its way through increasingly well-watered savanna grassland and range country to the tidal reaches where there are mountain ranges up to 300 metres high. Mesas and cliff-lined, flattopped ranges of broken sandstone and limestone border much of the Victoria River catchment or cut haphazardly across the valley floor through a mosaic of basalt and limestone plains. Ecologically, it is a rich and diverse region with vast Mitchell grass plains, dry 'desert' areas, scrublands, wetlands, and occasional patches of rainforest. Springs, billabongs and waterholes generally are common.

For the Aborigines it was a land of plenty, with plant foods, fish, reptiles, birds and mammals in abundance. At European contact the region was the home of at least eleven separate Aboriginal language groups ${ }^{1}$ with a total population of between 5500 and 16,500 people. $^{2}$ By comparison with other parts of Australia where radiocarbon dates have been obtained in archaeological excavations, the region has probably been occupied for at least 40,000 years. In contrast, European knowledge of the region spans less than 200 years.

For much of its European history the region was a backwater of the Territory, and very little ethnographic research was carried out there. There are a number of possible reasons for this. One is that the district was remote and difficult to access. Another is that the climate is harsh, with high temperatures and humidity for at least two-thirds of the year; ${ }^{3}$ and yet another is that there were no functioning Aborigines reserves, mission stations or towns to act as bases from which anthropologists could carry out

1. See northwest sheet of tribal boundaries map in Tindale 1974; map Lewis 1990: 9.

2. Birdsell (1953) suggested that a language-identified group tended to a mean of 500 persons. Based on his figures, the total population of the 11 language-identified groups in the Victoria River district would be 5500. Butlin (1983: 175) suggested that Birdsell's estimate should be increased by a factor of more than three. On this basis the Aboriginal population of the Victoria River district would be about 16,500.

3. Lee 1969: 220-45. 


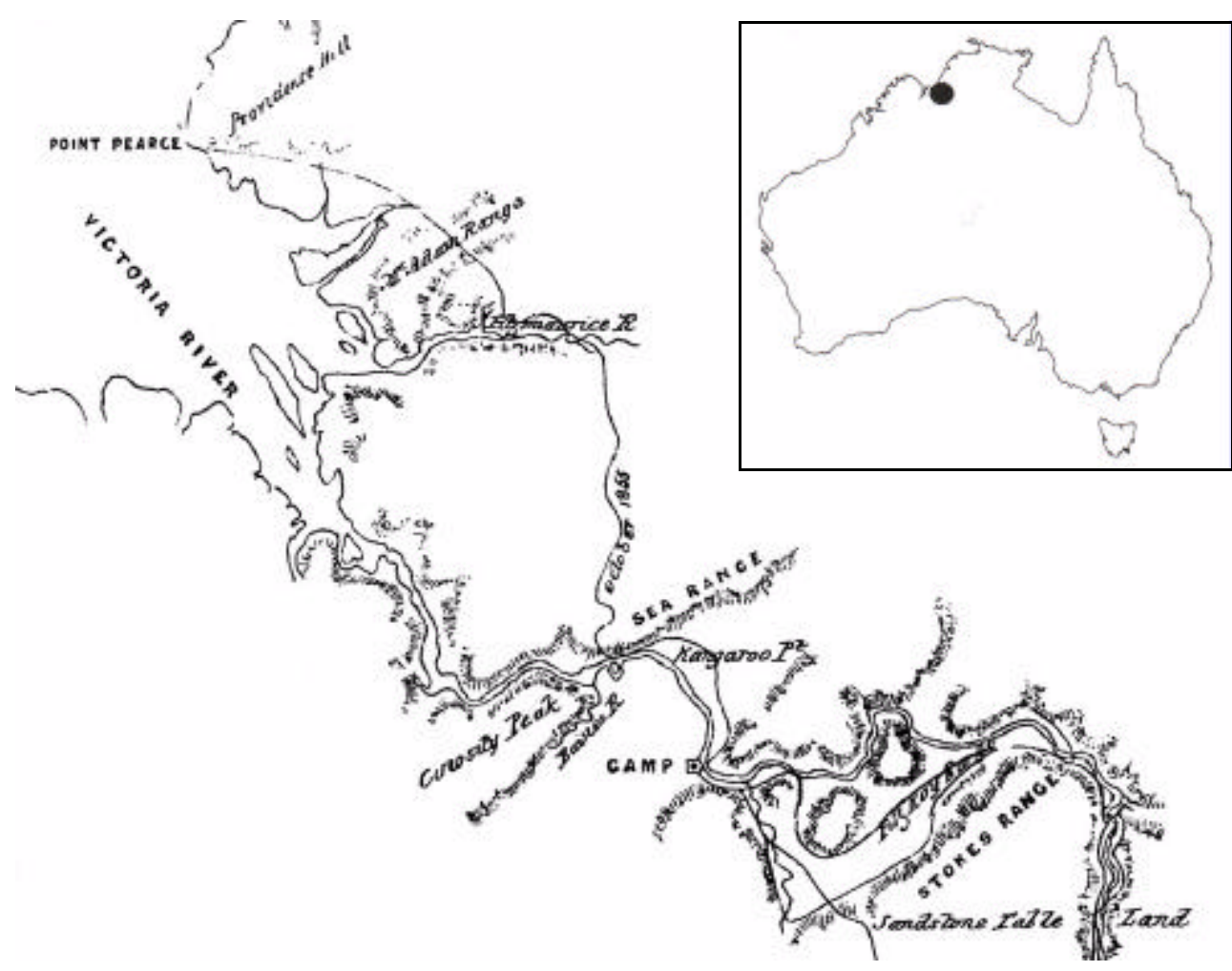

Figure 1: Location of the lower Victoria River, NT. Part of Gregory's original map of 1856 showing the depot camp and other placenames on the lower Victoria River. NBAC Map F246 Goldsbrough Mort Collection 2/859/378: Victoria River and Northern Territory Leases, Exploration by AC Gregory and party, Nov 1855-Jun 1856, nd. Noel Butlin Archives, ANU, Canberra.

research. As a result there are comparatively few records documenting local Aboriginal life in the early days of European settlement. However, some fascinating information about the Aborigines exists in the records of two exploring expeditions, and little of this information has ever been brought to the attention of researchers and others interested in the traditional life and history of Victoria River Aborigines. Presenting this information is the focus of this paper.

Two official exploring expeditions visited the lower Victoria River country in the nineteenth century - the Wickham-Stokes expedition of 1839 and Gregory's expedition of 1855-56. With respect to Aborigines, Stokes' accounts are brief but informative. Gregory's published accounts have even less to say about Aborigines, but a number of unpublished diaries and letters written by members of Gregory's expedition contain quite detailed information on both the environment and the Aboriginal inhabitants. These unpublished records provide basic descriptions of the appearance, dress and weapons of the Aborigines, and document the development of largely peaceful relations between the explorers and local people. Viewed through the lens of ethnographic studies carried out in recent times, the observations of the explorers also provide 
insights into traditional Aboriginal life at the point of contact, and beyond the material realm. Combined with the published reports, they provide a kind of 'foundational document' for Aboriginal life in the Victoria River district - a baseline from which to measure the changes wrought by European settlement.

There are similar 'baselines' in other parts of Australia - far too many to summarise here. However, it is clear that relations at each place developed in their own way, according to the 'rules of engagement' on each side, the determination or otherwise of the Europeans to maintain peaceful relations, the character of the individuals involved and no doubt other factors, and a few examples will suffice to illustrate this point. At Escape Cliffs settlement, established east of Darwin in 1864, there were numerous instances of serious conflict during the two years that the settlement lasted. ${ }^{4}$ However, in spite of some instances of conflict, at the new settlement established three years later at Darwin Harbour only 45 kilometres from Escape Cliffs, relations remained relatively peaceful. In this case it appears that both the Europeans and Aborigines had learnt from previous experience at Escape Cliffs and were more inclined to negotiate a peaceful relationship. ${ }^{5}$ At Sydney Cove relations alternated between peaceful encounter and hostility before general conflict broke out, ${ }^{6}$ but at Albany in southern Western Australia relatively peaceful relations developed between the Aborigines and the military men who established the initial outpost, and continued as the settlement grew. ${ }^{7}$

While the historical record indicates that conflict was almost inevitable wherever settlers came and took over the land, if the available records are to be believed there were rare exceptions. Robert Christison, the pioneer of Lammermoor station in western Queensland, is said to have established friendly relations with local Aborigines, ${ }^{8}$ and there is no record of any conflict with local people on Flora Valley station, East Kimberley, stocked by the Gordon Brothers in 1887. These brothers are said to have been determined to avoid the violence that had erupted at Wave Hill, stocked four years earlier, ${ }^{9}$ and their intentions may have been realised. Some years after they settled there Aborigines 'accidentally' speared a Flora Valley beast on a neighbouring station, and they came to the brothers and apologised, saying that they thought it belonged to the neighbour. ${ }^{10}$ On the lower Victoria River contact between the explorers and the Aborigines was mostly peaceful, but whether this state of affairs would have continued if the Europeans had remained in the area for a longer period is impossible to know.

\section{The Wickham-Stokes expedition: October-November 1839}

Official European knowledge of the Victoria River region began in October 1839 when the expedition led by Captain John Wickham arrived there in HMS Beagle. Wickham's expedition explored both the Fitzmaurice River and the Victoria River by boat to the head of the tidal reaches, but Wickham himself became ill before his explorations were complete so he handed responsibility to Lieutenant John Lort Stokes, and it was Stokes

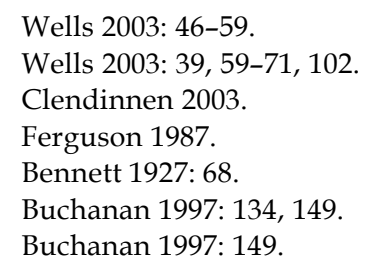


who led much of the exploration and who later wrote the only published account of the expedition. ${ }^{11}$ The Wickham-Stokes expedition was only on the Victoria for a month and did not establish a land-based depot, so there was little time or opportunity for the Aborigines to become sufficiently familiar with the whites to make sustained contact. As a result, the Europeans learnt very little about local Aboriginal society, but their notes enable us to make several observations.

First, as it passed along the tidal reaches of the Victoria (between the river mouth and 10-15 kilometres above Timber Creek), expedition members saw fires they attributed to Aborigines and found two rafts near Rugged Ridge, ${ }^{12}$ but they saw no Aborigines at all. ${ }^{13}$ Their apparent absence has at least two possible explanations. One is that as the white men moved up the river, news of their appearance may have been relayed to Aborigines further upstream. If this was so, the Aborigines may have hidden themselves and watched the strangers pass; while the explorers saw no Aborigines, the Aborigines almost certainly saw them. ${ }^{14}$

The other explanation concerns seasonal conditions. The expedition was on the river in October, at the end of the long winter dry season. In this region the arrival of the first storms of the wet season is highly variable. They can begin in September and be regular and frequent, but more often they begin in October or November and are infrequent. In any case, it takes a considerable time for the parched ground to become soaked and for runoff to occur, and until there has been sufficient rain to make the river flow the water in the tidal reach is too salty to drink. There are now very few freshwater billabongs or springs along the tidal section of the river and at the end of the dry season most of these are dry. ${ }^{15}$ If this was the case before the impact of cattle, most of the Aborigines who might otherwise have lived along the riverbanks were likely to be concentrated at water sources well out on the surrounding plains, in nearby ranges, or along the river above the tidal zone. This suggestion is strengthened by the fact that when Stokes led a foot party above the tidal reaches he quickly found evidence for an Aboriginal population so large that he began to worry about the possibility of attack.

From the head of the tidal reach Stokes' party walked upstream for six days, to a point close to the location of the present-day Coolibah homestead. Along the way they discovered an abandoned village of 13 paperbark huts, ${ }^{16}$ old campfires with the remains of turtles, mussels and crocodiles, and burnt-off areas. Then they began to see the Aborigines themselves. First they saw two children who fled into 'tall reeds', and shortly afterwards they saw 'three women carrying bundles of bark at their backs ... They were quite naked, with the exception of a slight covering of bark around their waists.' When the women saw them they called out and were answered by what

11. Stokes 1969 vol 2.

12. Rugged Ridge is located on the west bank of the Victoria River at co-ordinates 890090 on the Victoria River 1:100,000 map, sheet 4867.

13. Stokes 1969 vol 2: 40-63.

14. Similar reactions to the appearance of Europeans were documented throughout Australia. See Mulvaney 1989: chapter 1; Reynolds 1981: chapter 1.

15. These observations are my own, based on 35 years experience of the area.

16. Stokes 1969 vol 2: 69. 
sounded like a large party nearby, which caused the explorers to hurriedly move on. ${ }^{17}$ Later that day they saw a party of natives cross the Victoria and head downstream. ${ }^{18}$

There can be little doubt that on this section of the river, at least, the Aborigines quickly discovered the white intruders and kept them under observation, and eventually some decided to make contact. When Stokes' party was resting on the riverbank in the vicinity of 8 Mile Yard on present-day Coolibah station, they heard 'the shrill voices of an evidently large body of natives'. ${ }^{19}$ The explorers prepared themselves for attack, but instead they experienced a peaceful encounter:

Two natives, accompanied by a large cream-coloured dog that howled mournfully, came down suddenly, shouting "Ho! ho!" upon the opposite bank, as though more clearly to reconnoitre our position. They were fine looking men, with bushy hair and spare limbs, quite naked, and apparently unarmed - a usual indication among the aborigines of Australia that their intentions are peaceful. They amused themselves for a time by making all sorts of gestures, shouting still "ho! ho!" to those of their body in concealment ... I was of course very glad that no appeal to force was necessary ... against those to whom we appeared in the character of invaders of a peaceful country. ${ }^{20}$

This was the closest contact with Victoria River Aborigines experienced by anyone on the Wickham-Stokes expedition. After unsuccessfully trying to communicate the Aborigines eventually withdrew, leaving Stokes to remark that

the condition and appearance of the two who made themselves visible, indicated their residence in a country fitted to supply abundantly all natural wants ... I could not help comparing the bold, fearless manner in which they came towards us - their fine manly bearing, head erect, no crouching or quailing of eye - with the miserable objects I had seen at Sydney. I now beheld man in his wild state; and reader, rest assured there is nothing can equal such a sight. Before me stood two of the aboriginal inhabitants of Australia who had never, until then, encountered the hitherto blighting look of an European. ${ }^{21}$

When the explorers finally returned to their boats they learned that some expedition men hunting on a hillside had seen a large party of Aborigines 'crawling along the ground with evident caution' ${ }^{\prime 2}$ towards a watering party. Stokes assumed that the Aborigines were 'intending if possible to surprise them', but it is at least as likely to be an example of the Aborigines keeping out of sight and cautiously sneaking up to satisfy their curiosity about the strange white men.

Even though his explorations did not extend beyond the lower Victoria River, Stokes painted a glowing picture of the region and his report was an encouragement to further exploration. Before leaving the Victoria he expressed the desire that, 'ere the sand of my life-glass has run out ... smoke may rise from Christian hearths where now alone the prowling heathen lights his fire' ${ }^{23}$ Stokes died on 11 June $1885,{ }^{24}$ just two

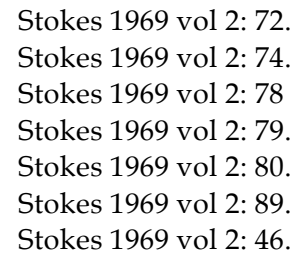


years after the first (at least nominally) Christian hearths appeared on the Victoria. The irony is that today there may well be more Aboriginal Christians in the district than there are European Christians, and over the years many of the local whites could easily have qualified as 'prowling heathens'.

\section{The Gregory expedition: October 1855 to July 1856}

For sixteen years after Stokes left, the Aborigines were left in peace. Then in 1855 an expedition led by Augustus Gregory was sent to explore the upper Victoria River and to determine whether it might in fact be a 'highway' into the interior of Australia, perhaps even to the fabled inland sea. ${ }^{25}$ Due to an accident on board the ship carrying the expedition horses, and because a landing place could not be found as far up the Victoria River as Blunder Bay, the horses had to be landed near Port Keats. From there a small party led by Gregory travelled overland, through the broken country of the Fitzmaurice River valley and across to the Victoria River, ${ }^{26}$ while the other expedition members continued on to the Victoria in the expedition ship Tom Tough, with the intention of setting up a base camp from which inland expedition could take place. $^{27}$

A depot camp was soon established at a point about 10 kilometres below Timber Creek and from there Gregory made a number of forays into the interior, far beyond the point reached by Stokes, eventually travelling right up to the watershed and beyond, down the inland-flowing Sturt Creek to where it ends in a huge salt lake. ${ }^{28}$ When Gregory eventually returned to the main base camp the expedition broke up, and Gregory started off with a group on horseback to travel 3200 kilometres across northern Australia and down to Moreton Bay (Brisbane). ${ }^{29}$ The remaining expeditioners boarded the Tom Tough and left to obtain provisions at Kopang and then to sail to the Albert River in the Gulf of Carpentaria for a rendezvous with the overland party. ${ }^{30}$

\section{Expedition records}

Within a few years of the end of Gregory's expedition a number of expedition members published papers relevant to their own expertise and experience, but the only detailed published accounts of the expedition are the reports by Gregory. ${ }^{31}$ These provide relatively short day-by-day descriptions of events and through reading these alone it would be easy to imagine that the expedition had minimal contact with Aborigines. However, the men in charge of the depot camp while Gregory was away kept an official camp journal, and some kept personal diaries and wrote letters to friends and family in England, some of which have been preserved in archives. ${ }^{32}$ They document a number of significant encounters between the explorers and the Aborigines, and reveal a poignant 'what might have been' in view of later race relations in the region. In combination with Gregory's journal and the published papers, they provide an insight

24. Hordern 1990.

25. Cumpston 1972: 110; Wickham, 'Description of the River Victoria on the N.W. coast of New Holland', p 41. Mitchell Library A308 (microfilm copy at CY 2627, frames 91-117).

26. Gregory 1884 [1981]: 102-7.

27. Gregory 1884 [1981]: 102.

28. Gregory 1884 [1981]: 138.

29. Gregory 1884 [1981]: 152-4.

30. Gregory 1884 [1981]: 154

31. Gregory $1857,1858,1884$ [1981]. 
into many aspects of Aboriginal society at the time - people's physical appearance, their material culture, social relations and land use - and their varied reactions to the Europeans. They also suggest a greater awareness of Europeans than might otherwise have been expected.

Gregory's personal experience of Victoria River Aborigines was similar to that of members of the Wickham-Stokes expedition. His journal records that during his inland forays he often saw signs of Aborigines and occasionally heard them calling, but he had only a few fleeting glimpses of the people themselves. ${ }^{33}$ Understandably, his journal is primarily concerned with what he experienced himself, and although the depot was permanently manned for nine months, Gregory himself spent only half that time there. As a result, his journal provides scant detail about the experiences of the men who stayed there while he was away. For example, on his return from his second excursion inland Gregory recorded that during his absence, 'The natives have been frequently at the camp in small parties, and on these occasions were very quiet in their demeanour'. He was also told that Aborigines met by small detached parties of men away from the base camp had made 'hostile demonstrations', and on one occasion had to be fired on, with one man being slightly wounded. ${ }^{34}$ Gregory's brief and dry journal entries gloss over these events; far more occurred between the Aborigines and the men stationed at the depot camp than either Gregory's journal or later books about his expedition would suggest. Furthermore, not all encounters away from the base camp were hostile.

\section{Discovering each other}

When the expedition ship Tom Tough moved up the Victoria River, no Aborigines were seen along the 140 kilometres of tidal reach. Like the Wickham-Stokes expedition before them, Gregory's men moved up the river in October. Once again, the Aborigines are likely to have been elsewhere and any who remained probably hid themselves. One distant bushfire was seen, and in a remarkable coincidence with the experience of Wickham and Stokes, near Rugged Ridge Gregory's men discovered 'floats' made from a very light mangrove wood. ${ }^{35}$ A sketch of these floats made by Thomas Baines shows several bound together, and stakes protruding from the trunks, probably placed there to hold spears and other belongings in place. ${ }^{36}$

Initial contacts were either cautious and low key, or unfriendly. The first 'cheek by jowl' encounter occurred on 16 November when Gregory was leading a party on a short

32. JR Elsey National Library of Australia Ms 25; JS Wilson and JR Elsey, Journal kept at the main camp, ... 1856, entry for January 5 1856, Mitchell Library ZC 411-1; JS Wilson, Journal..., entry for January 31 1856, Mitchell Library ZC 411-2; letter from JR Elsey to his 'beloved parents', nd, written over an extended period at Victoria River Depot, NLA Ms 25/5; letter from JR Elsey to 'Dear John' 1856, NLA Ms 25/4.

33. Gregory 1884 [1981]: 126, 132, 134, 140-1, 147, 149-50.

34. Gregory 1884 [1981]: 150-1.

35. JS Wilson (1858: 152) mentions the use of 'rafts'. A sketch of these 'rafts' by Thomas Baines is dated 27 September 1855. (A copy of this drawing is held at the NLA in the Thomas Baines collection.) This indicates that they were discovered during a reconnaissance to Blunder Bay in search of a landing place for the horses, which were still on board the expedition's second ship, the Monarch, near Point Pearce (Gregory 1884 [1981]: 102).

36. Thomas Baines collection, NLA. 
reconnaissance to the freshwater reaches of the river. At Palm Island, eight kilometres above the mouth of Timber Creek,

A native approached the bank of the river and came to us, and a parley commenced which was rather unintelligible, and when he found that he could not make himself understood by words, resorted to the language of signs, and expressed his contempt of us in an unmistakable manner. ${ }^{37}$

During the following week or so, Aborigines twice visited a party cutting trees at Timber Creek. While these visits were described as 'neither decidedly friendly or hostile', the Aborigines pilfered some items 'imprudently left lying near one of the logs' and later 'set fire to the grass about 200 yards from the camp, and then retired'. ${ }^{38}$ In December two men looking for strayed horses about 25 kilometres to the west thought themselves threatened by a large group of Aborigines; they scattered them by charging them on horseback. ${ }^{39}$

Gregory set out on his second and major excursion inland on 2 January 1856. Two days later two crewmen from the Tom Tough were hunting across the river from the depot when four Aborigines appeared. One of the hunters was already on his way back across the river with a kangaroo he had shot, so Captain Gourlay went over to pick up the other crewman, and Wilson recorded in the camp journal that:

During the time he was ashore the Capt'n had a parley with the Natives and observed that they spoke a few words of English. One asked for tobacco and seemed to understand its use perfectly when a small piece was given him - he said tomorrow in a manner that the Captain understood to mean, that they would come tomorrow. Mosquitos being exceedingly troublesome to him he would strike the place where they stung him with his hand and say, no good, no good. ${ }^{40}$

In spite of the friendly nature of this meeting, Wilson was afraid of problems arising if similar incidents occurred, so he gave orders that no hunting was to be done on the opposite side of the river as long as Aborigines were in the area. ${ }^{41}$ The same Aborigines appeared at the same place the next day but were ignored. They came again the next day, and the next, and were ignored each time. ${ }^{42}$ In the meantime work was begun on digging a defensive ditch around the depot camp to give it a degree of protection against possible attack, and to serve as a boundary line inside which Aborigines were not to be allowed. ${ }^{43}$

Wilson was perplexed at the apparent use by the Aborigine of the English words 'no good', 'tomorrow', and 'tobac' and his apparent knowledge of the use of tobacco, and he speculated that when the British settlement at Port Essington existed (1838-49) ${ }^{44}$ Aborigines living in the area might have learnt 'a considerable number of English

37. Gregory 1884 [1981]: 112

38. Gregory 1884 [1981]: 112-13.

39. Gregory 1884 [1981]: 118. The men were Thomas Baines and R Bowman. Baines later recreated this encounter in an oil painting, a copy of which is reproduced in Braddon 1986: 37.

40. Wilson and Elsey 1856, entry for 3 January 1856.

41. Wilson and Elsey 1856, entry for 5 January 1856.

42. Wilson and Elsey 1856, entry for 5 January 1856.

43. Wilson and Elsey 1856, entry for 7 January 1856

44. Spillett 1972. 
words' and transmitted them to the neighbouring tribes. He noted that the man who appeared to use English words was older than his companions, and might have learnt the words he used (and gained a knowledge of tobacco) when he was living with Aborigines much further to the north. ${ }^{45}$

Wilson's speculations that English words and knowledge of tobacco may have been passed from tribe to tribe from the old Port Essington settlement were quite possibly correct. In fact, there is no reason to deny the possibility and good reason to assume it was the case. It is now well-known that Aborigines throughout Australia were connected to each other via trade and information networks. ${ }^{46}$ Explorers elsewhere in Australia were often surprised to meet Aborigines far beyond the frontier who possessed European goods and even some words of English such as 'white fellow' and 'majkat' (or similar variations) for musket. ${ }^{47}$ George Windsor Earl, the official linguist and draughtsman at Port Essington, ${ }^{48}$ noted that information passed rapidly from tribe to tribe, so that 'an event of any importance is known over a large extent of country in the course of a very few months'. He also noted with surprise that Aborigines visiting from further inland spoke of 'white people who dwelt in the country to the south, and who built houses of stone', and he assumed that this must refer to houses in the infant settlement of Adelaide, over 3000 kilometres away. ${ }^{49}$

Similarly, when explorer Ludwig Leichhardt first entered the plains of the South Alligator River in November 1845, he met Aborigines who repeatedly said the words 'perikot' and 'nokot'. Because of their accent, at the time Leichhardt did not recognise what the Aborigines were saying, but later he realised the words were 'very good' and 'no good'. 50 This was about 200 kilometres from Port Essington, and apparently these words were used so often by the whites there, and with such emphasis, that they made a impact on the Aborigines who heard them and were passed along from tribe to tribe to this place. It is of interest to note that among the Larrakia Aborigines in the Darwin area, 'perikot' is the term they now use for 'white man' ${ }^{51}$

Months after the first encounter with the supposedly English-speaking Aborigine, expedition surgeon and zoologist Joseph Elsey had an opportunity to converse with him (see below) and as a result he rejected the claim that any local Aborigines knew words of English, although he admitted that several words sounded like 'tobac' and 'no good' ${ }^{52}$ Given that Leichhardt had not recognized the words 'very good' and 'no good' after more than four years experience of listening to Aboriginal English, it is quite possible that the Victoria River Aborigines were attempting to speak English and that Elsey was not experienced enough to understand what he was hearing. In addition, the facts remain, first, that upon (apparently) asking for 'tobac' and being given a piece, the Aboriginal man 'seemed to understand its use perfectly' - the implication being that

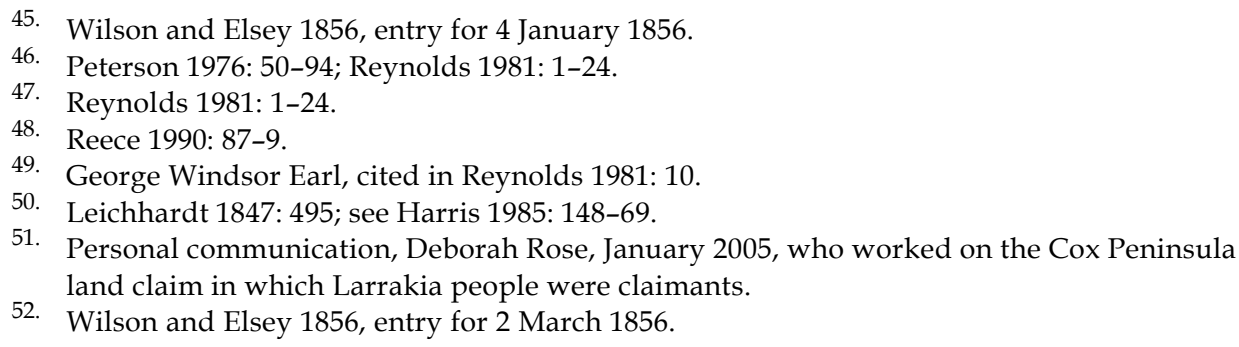


he began chewing it - and second, that he apparently said 'tomorrow' and did indeed come back the next day.

Apart from the discovery of some footprints near the depot camp on 18 January, 53 the Aborigines seem to disappear from the depot area for six weeks, but down river below the Angalarri Creek junction there were remarkable encounters on 31 January, 1 February and 3 February. On 31 January Wilson, Captain Gourlay and some sailors set off by boat from the depot camp to look for a suitable place to careen the Tom Tough so that repairs could be carried out. Darkness had fallen as they neared the Sea (now Yambarran) Range when they noticed some Aboriginal campfires. Some of Wilson's men 'cooeed' but got no answer, so Wilson ordered a gun to be fired. Upon hearing the gunshot one might have expected the Aborigines to flee, but instead they began calling to the Europeans and one came towards them with a firestick. This suggests that they had become familiar with the sound and use of firearms, probably while watching the Europeans from hiding. The two groups kept calling to one another as the boat passed, but no contact was made and shortly afterwards the Europeans camped for the night. ${ }^{54}$

The next day saw the most extraordinary encounter of the entire expedition. A few minutes after Wilson and his men resumed their journey downstream they were again hailed by Aborigines. Wilson directed his men to keep going and the Aborigines followed them by running along the riverbank. Eventually his party pulled up on the opposite bank for breakfast, and the Aborigines who had followed them gathered to watch. ${ }^{55}$

As the explorers landed they shot at a flock of cockatoos feeding on wild melons growing there and 'as they rose and were flying overhead one of the men fired up amongst them'. A cockatoo fell from the sky and Aborigines watching from across the river, 'simultaneously gave a yell of mixed admiration and astonishment' ${ }^{56}$ Some of Wilson's men went into the nearby bush to try and shoot more game but they soon hurried back, saying they had been hailed by what seemed to be another large group of Aborigines. A conversation ensued between the Aborigines on both sides of the river, and as a result,

Nine of those on the off side marched into the water until out of their depth, then swam to a sandbank in the middle across which they marched in the same regular order and again swam toward the bank carrying their spears above water in the left hand. As they approached the bank (about 200 yards below where our boat was moored), an elderly native swam out to meet them bearing in his hand a green bough. The green bough, the well known emblem of peace. ${ }^{5}$

In Aboriginal society, generally, old men and old women are the leaders in ritual events. ${ }^{58}$ The fact that the group crossing the river was met by an old man carrying a green bough clearly indicates that the Aborigines on each side of the river were from different social groups and coming together for peaceful purposes, most probably a rit-

\footnotetext{
53. Wilson and Elsey 1856, entry for 18 January 1856.

54. Wilson 1856, entry for 31 January 1856.

55. Wilson 1856, entry for 1 February 1856.

56. Wilson 1856, entry for 1 February 1856

57. Wilson 1856, entry for 1 February 1856.

58. Palmer 1994: 943-5.
} 
ual gathering. Of course, Wilson had no way of knowing this. He and his men feared an attack so they loaded their muskets and then 'stood on the high bank and expressed in high terms their admiration of the novel scene ... The place added materially to the effect. The broad river, the repulsive red cliffs of Sea Range, the picturesque Dome ${ }^{59}$ in the back ground. ${ }^{60}$

The two groups of Aborigines came together some distance away and then came, unarmed, towards the Europeans. All of them were young men except for one 'rather elderly man' with 'an abundant beard' ${ }^{61}$ who came on about 30 yards in advance of the others. Still fearing an attack, Wilson's party made signs for them to stop. The elderly man in the lead apparently understood these signs and ordered his countrymen to keep back. He then 'trampled down the long grass round where he stood to show that he had no concealed weapon', and pointed to a running sore on his back. Wilson's men were still fearful and wanted to drive the Aborigines away, but Wilson ordered them to hold their fire, making the rather droll remark that the Aborigines 'came rather to have their wounds healed than to have others added'. He and his men then went up to the injured man.

The expedition surgeon was not with Wilson's party and they had no medicines, so after some discussion they improvised a treatment. First, one of the men prepared a quid of tobacco. Then, believing he needed to convince the Aborigines that powerful magic was involved, he

Muttered a lot of gibberish performed a number of gymnastic movements, which ended (muttering all the time) by taking off his hat looking at the sun, first over his right shoulder then over his left and dashing his hat with violence to the ground proceeded to apply the solaceing [sic] weed. ${ }^{62}$

The quid of tobacco was then bound in place with a strip torn from the man's shirt. The puzzle is, what made the injured man think that these strange intruders could help with his wound? Although nothing can be said with certainty, it may be that along with English words and knowledge of tobacco, word had come that the Europeans at Port Essington were good at healing wounds and curing sickness.

While this 'treatment' was in progress the crewmen had approached the other Aborigines and 'an amicable understanding established'. Wilson thought that the friendliness of the Aborigines was probably due to the 'peaceful and distant disposition' the expedition members had maintained since they had arrived, and because the Aborigines 'had evidence of, and felt our superiority' ${ }^{63}$

According to Wilson, the Aborigines indicated that they knew of the expedition's depot camp and seemed anxious to make a visit. He also believed that they invited him to a corroboree at their camp that night (and he was almost certainly correct), but he

59. The 'Dome' is a conical hill on the east bank of the Victoria River at the very end of the Yambarran Range' (Millik Monmir 1:100,000 map, sheet 4967, co-ordinates 284 981).

60. Wilson 1856, entry for 1 February 1856.

61. The scene described here occurred on 1 February but the reference to the elderly man having an abundant beard is in the entry for the following day (Wilson 1856, entry for 2 February 1856).

62. Wilson 1856 , entry for 1 February 1856

63. Wilson 1856, entry for 1 February 1856. 
declined. He and his men then finished their breakfast, gave the Aborigines a few small gifts, and continued on downstream. The Aborigines followed them along the bank for a distance but were eventually left behind. Then, as Wilson's party was passing the Dome, a large group of women, children and old men watched them from the hillside and called out to them, but once again the Europeans continued on. ${ }^{64}$ In the Victoria River district today many rituals are fully or partly gender-specific and it is likely that these people were keeping out of sight of a male-only ritual about to take place. ${ }^{65}$

On their return upstream two days later Wilson and his men camped near where they had met the large group, and they had another peaceful encounter. This time there were only six men, four that they had seen before and two others who were very young and who 'stood aloof.' Wilson noted that the four older men 'seem to have their teeth ground down to an even Surface' and that

They may be considered to be about the Middle Stature, but are so very slender that they appear taller when at a little distance. They have generally very thin beards, yet they seem to value and admire that gift of Nature. One (who seemed the most intelijent) [sic] had enough on his chin to allow of its being drawn together and tied had the tip of a Kangaroo's tail added to it to increase its length ... They practice the rite of Circumcision but whether it be with them a religious rite remains to be learned. They wear no clothing with the exception of a belt made of bark and bound round the body with about a dozen plies of chord [sic]. ${ }^{66}$

Unlike the older men, the two young men who 'stood aloof' had their two front teeth knocked out and Wilson was 'given to understand by the others that they belonged to another tribe up the River' ${ }^{67}$ Later on at the depot other Aborigines were seen with their front teeth missing (see below) so it is unlikely the two young men in this group were missing their teeth through accident or fighting. Tooth avulsion as part of initiation rituals was once a widespread practice in Australia. ${ }^{68}$ In the Victoria River district today there are several different rituals through which boys are made into young men. These are Pantimi, Wanga, and Yalaju, ${ }^{69}$ but none of them involve tooth avulsion. However, the fact that some men seen by expedition members had all their teeth and others had the two upper front teeth missing suggests that tooth avulsion was practiced in the past by some and that, like today, there were variations in initiation rites. It is highly likely that the young men with their teeth knocked out were undergoing 'young men's' initiation - the initiation of boys into the first stage of manhood. In the Victoria River district this is a prolonged process during which the neophytes are largely removed from society, placed under the strict control of initiated men, and taken on trips into the territory of neighbouring groups. ${ }^{70}$ Young men undergoing this stage of initiation are quite constrained in their social interactions and can appear

Wilson 1856, entry for 1 February 1856

65. Rose 1992: 28.

66. Wilson 1856, entry for 3 February 1856.

67. Wilson 1856, entry for 3 February 1856.

68. Horton 1994: 1086; the practice was reported at Port Essington in 1843 (H Melville, cited in Mulvaney 1989: 70).

69. Rose 1992: 55.

70. Rose 1992: 145-9; MJ Meggitt (1974: 36, 46, 233, 285) reports a similar 'grand tour' of initiates in Walbiri country, immediately south of the Victoria River. 
'aloof' when spoken to by strangers or by inappropriate people. Whether the ceremony about to take place was a 'young man's initiation' or a ritual focusing on an older agegroup is unclear. In historical times in Walbiri country, immediately south of the Victoria River district, neophytes were allowed to view the rituals involving older men. ${ }^{71}$

Wilson's description of the Aborigines does not mention body scarring, but this feature is remarked upon later by Elsey. ${ }^{72}$ In the Victoria River district and elsewhere in historical times, scarring of the chest and arms of men signified that they had gone through the major initiation rites (known as Gadjari or 'Big Sunday' in the Top End of the Northern Territory) and achieved full manhood. It is likely that the scarring noted by Elsey also signified the attainment of full manhood by Aboriginal men. The practice continued well into historical times, and although these ceremonies are still held in the Victoria River region, body scarring appears to have ceased within the last few decades.

To return to the meeting between Wilson's party and the six Aborigines, the men in this group were fascinated with the physical appearance of the Europeans and in a manner strangely reminiscent of late 19th and early 20th century anthropological studies of Aborigines, ${ }^{73}$ they examined them 'with extreme minuteness'. They noted that not all of the whites had hair of the same colour and were astonished at their 'superior muscular proportions which they observed with admiration'. One man opened Wilson's shirt and examined his chest 'with the minuteness that a Military Doctor might be supposed to do that of a young recruit'. Possibly he was looking for chest scars as evidence that he was dealing with a fully initiated man. Then he compared each part of Wilson's arm with the same parts of his own. He noted that Wilson's hand was not as large as his own and called to one of his friends to come and look at the difference. While the second man was holding Wilson's hand in his own, Wilson grasped it as hard as he could, causing the man to wince and sing out. According to Wilson all the Aborigines laughed and the butt of his joke 'seemed both pleased and astonished while he rubbed his hand and described his sensations to his brethren' ${ }^{74}$

The men with Wilson then began to barter with the Aborigines and exchanged a blanket and a red woollen shirt for two spears. They were keen to obtain a stone tomahawk but Wilson noticed that the Aborigines seemed to value these very highly, and in a perceptive and considerate insight he admonished his men to only trade something which would be of equal service to the Aborigines. The Aborigines had two stone hatchets, 'one ... made from a fragment of trap, the other of Syenite'. Wilson was intrigued by the axe of syenite ${ }^{75}$ because he had examined the 'drift of the Victoria' but never seen this type of stone, and he remarked that he 'could obtain no information from the natives relative to the locality in which it had been obtained. My impression was that it originally belonged to some tribe up the Adelaide and had passed from them through the intermediate tribes. ${ }^{76}$ In a general sense Wilson's surmise was proba-

\footnotetext{
Meggitt 1974: 234.

Wilson and Elsey 1856, entry for 2 March 1856.

For example, see Stirling 1966; Campbell and Lewis 1926; Fenner 1936: 46-54.

Wilson 1856, entry for 2 February 1856.

75. According to the Macquarie Dictionary (Macquarie Library Pty Ltd, Sydney, 1981: 1770), syenite is 'a granular igneous rock consisting typically of felspar (orthoclase) and hornblende.'
} 
bly on target. It is, of course, well known that artefacts and other items were and are traded from tribe to tribe, ${ }^{77}$ but whether this particular hatchet came from the Adelaide River area cannot be determined. Eventually the Europeans and Aborigines parted 'in the most amicable manner' and the Aborigines followed the boat for some distance before dropping out of sight. ${ }^{78}$

The next encounter occurred at the depot camp over a month later. On 2 March Elsey was in a gully above the camp when he was alarmed to see three Aborigines approaching. He rushed back to camp to wait for them at the embankment, and described how

they came forward boldly, and the eldest of them walked directly up to me \& jumping the ditch, stood by my side. I immediately intimated that he must recross the ditch whereon he jumped back laid down his spears \& woomera \& jumped back again, but it was not till I pushed him over that he seemed to understand that neither he nor his weapons were to cross the ditch. They were very cheerful \& communicative, but had no Knowledge of English, though several words sounded very much like "tobac" "no good" \&c. 79

According to Elsey these Aborigines

were all in very fair condition had the two upper front teeth knocked out \& wore a tassel in front fastened round the loins. The two youngest had the hair fastened with a white band, that of the eldest was loose in front, close shaven behind. They had a centre tuft of their beard twisted up with the tip of a kangaroo tail, or matted together with gum. They were also freely but irregularly marked with long scars across the breast \& over the shoulder joint ... They each carried long spears, a woomera, \& two of them a bundle of sticks for making fire by friction, rubbing one into a hole in another; also a roll of dry tea tree bark for tinder. ${ }^{80}$

After a time Elsey went to his hut to get the Aborigines some old clothes and when he returned he found the oldest of them back inside the ditch again. Elsey got him outside the ditch once more, and somehow made it clear that he must stay out. He then 'gave him an old merino waistcoat, the second an old pair of drawers \& the third a finely made handsome youth, an old silk handkerchief to tie round his head'. After about an hour they left and 'promised to renew their visit' ${ }^{81}$

While Elsey was dealing with these Aborigines, Wilson and his party were in a boat on their way back to the depot. On the morning of 2 March his men were trying to shoot some cockatoos in the trees a short distance below the mouth of Timber Creek when they came upon a large group of Aborigines. Some had climbed high into trees to watch their approach while others were on a high rocky bank that jutted out into the river. ${ }^{82}$ They called out and invited the whites to land, 'but not liking appearances about them' Wilson directed the boat to move further towards midstream. As they

\footnotetext{
Wilson 1856, entry for 2 February 1856.

Mulvaney 1976: 72-94.

Wilson 1856, entry for 3 February 1856.

Wilson 1856, entry for 3 February 1856.

. Wilson and Elsey 1856, entry for 2 March 1856.

81. Wilson and Elsey 1856, entry for 2 March 1856.

82. Wilson 1856, entry for 3 March 1856.
} 
passed the Aborigines the boatmen noticed three of them standing hidden in the shade of a bush with their spears fixed in their woomeras. At the command of an old man, one of the three men ran as close as he could and prepared to throw his spear at them. A shot was fired in his direction and his arm dropped 'as though it had been shot down.' In fright he ran back to his friends and then a gun loaded with shot and ball was fired at the Aborigines. The whites saw the ball hit the rocks and miss the Aborigines, but some of the shot may have hit them 'as several of them jumped as though they had been struck unexpectedly, and they all scampered off across the rocks yelling like so many frightened imps'. Wilson did not believe that any of the Aborigines had been seriously injured, but he thought it would be 'a sufficient warning to them' not to try and throw spears at the white men again. ${ }^{83}$

Clearly this spear-throwing incident was not an all-out attack because if real aggression had been involved most of the men present would have thrown their spears and other weapons. Instead, it appears to have been an example of Aboriginal 'testing' of a new situation or group, as described by anthropologist Deborah Rose. ${ }^{84}$ Throwing a few spears enabled the Aborigines to discover in what manner and how well the white men were able to defend themselves, and consequently, whether they should be friendly or aggressive. It is fortunate for the explorers that none of the Aborigines was seriously injured or killed, or subsequent events may have been quite different.

In a note at the end of this journal entry Wilson described how, soon after his return, Elsey made a trip upstream to Reach Hopeless (about 12 kilometres above Timber Creek). As he began his return, he found himself cut off when Aborigines appeared on both banks. ${ }^{85}$ Luckily they proved friendly. Some were the men that Elsey had seen at the depot camp a few days earlier and several others were in the group that Wilson's men had fired upon the previous day. ${ }^{86}$ According to Wilson, these men

seemed anxious to explain [to Elsey] some affair which he supposed to be their meeting with us, and one of them a young fellow showed him two small fresh scars on his arm from bird shot wounds, [and] he patted the gun in a conciliatory manner. Since then he has been met with several times and has been to the camp, but always with expressions of good feeling. ${ }^{87}$

From this time it is clear that relations between the Europeans and the Aborigines improved rapidly. On 28 March Elsey recorded that 'In the afternoon the natives again appeared on the opposite side of the river \& were soon recognised as our acquaintances up the river by their calling out "bit of sugar" \&c' ${ }^{88}$ The Aborigines appeared across the river again on the following two days, and on both occasions Elsey and others went over to them. On the first occasion Elsey wrote that the Aborigines 'were without arms, very friendly \& merry \& one of them at last understood my endeavours to catch some

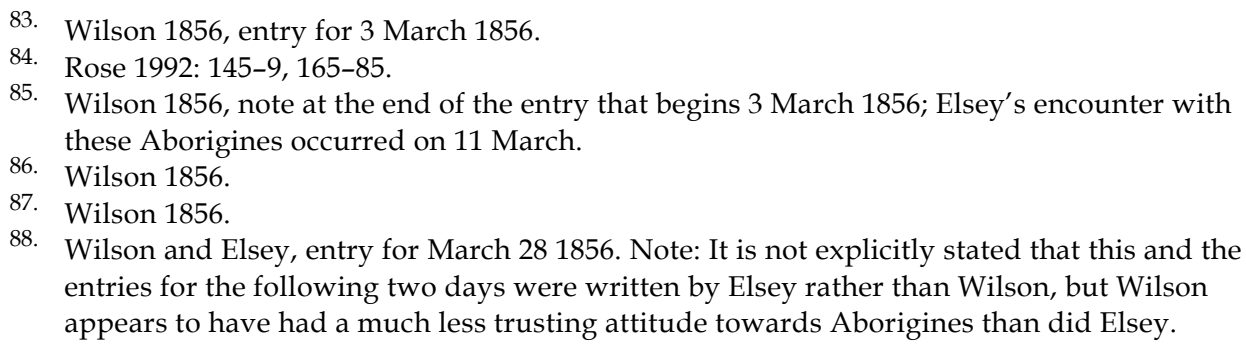


of their words \& gave us a number by which we were enabled to ask for a stone tomahawk, which they promised to bring the next day' ${ }^{89}$

The Aborigines returned the next day, bringing with them two stone tomahawks, and Elsey added to his word list, recording twenty words of the local language, 'most of them signifying parts of the body' ${ }^{90}$ Unfortunately, these word lists are not to be found in any of the surviving records from the expedition.

While the Aborigines were in the area across the river they fired the grass which burnt well, and this prompted Elsey to remark that, 'since Thursday 27th March there has been a brown fog all round the horizon ... This and other fires on both were probably the cause of this dry fog which rendered the air very close \& hot' ${ }^{91}$ During the next six weeks, at least, fires or smoke was seen in all directions; ${ }^{92}$ clearly the wet season had ended and the burning of country typical of Aboriginal land management across much of Australia had begun. ${ }^{93}$

Aborigines came to the depot camp again on 13 April and Elsey later wrote in the Camp Journal that

At dinner time two of our black friends, Deana \& Dearbigen made their appearance, and begged some clothes for their gins. I gave one a cotton waistcoat, the other a pair of drawers. They gave me a few additional words of their vocabulary, and were greatly astonished at the sketches in Stokes' works, especially of their own drawings 94 , to most of which they gave names. ${ }^{95}$

Additional details of this meeting were given by Elsey in a letter he wrote to 'Dear John' that same day. Curiously, the names he gave for the two Aborigines are different, but there can be no doubt that they are the same men:

I was roused from my solitary dinner of preserved beef \& rice ... by the cry "Doctor, there are natives coming to the camp," so I was obliged to jump up, take down my rifle, and gird on my revolver and march out to meet them. They proved to be two old friends, Drand \& Deartijero, with whom I had become very intimate during a voyage up the river. When I had satisfied their modest desires, frightened them with a looking glass, astounded them with a telescope, and presented one with an old merino waistcoat \& the other with a pair of cotton drawers cut off at the knee, both being singularly suitable garments for bush wear. ${ }^{96}$

Through both the journal entry and the letter, Deana and Dearbigen (or Drand and Deartijero) become the first Aborigines in the Victoria River district to appear as individuals in the historical record, and this highlights the familiarity that was develop-

89. Wilson and Elsey, entry for 29 March 1856.

90. Wilson and Elsey, entry for 30 March 1856.

91. Wilson and Elsey, entry for 30 March 1856.

92. Wilson and Elsey, entries for 20 and 22 April, and 6 and 9 May.

93. Horton 1994: 365-6.

94. On page 170 of volume two of Stokes (1969) there are illustrations of Aboriginal rock engravings from Depuch Island, Western Australia. Presumably these are the pictures shown to the Aborigines.

95. Wilson and Elsey 1856, entry for 13 April 1856.

96. Letter from J Elsey to 'Dear John', 13 April 1856, NLA Ms 25/4. 
ing between the explorers at the depot camp and some of the local people. The two Aborigines came to the camp again the next day, and Elsey

had a long chat with them, \& obtained a number of words \& was surprised to find that they understood the use of the boomerang which they call Karlee. They do not appear to use it themselves, but described with great exactness its course \& the peculiar sound it makes in its passage. A still more interesting fact to me was that they recognised at once a drawing of the Australian Porcupine Anteater, or Echidna, \& pointing to some ants which were attacking a brown snake we had given them, intimated that they constituted its food. ${ }^{97}$

Apparently Elsey was surprised at their knowledge of boomerangs because he never saw one in their possession. The absence of boomerangs directly parallels the situation today; Aborigines on the lower Victoria River do not make boomerangs, but obtain them via trade from the south. Those they now receive are fighting boomerangs rather than the returning type, and are used primarily as clap-sticks during ceremonies.

There was another visit by Aborigines to the depot on 27 April, but no details were given. ${ }^{98}$ On the morning of 10 April Wilson was on board the Tom Tough where it was careened near the Dome, when 'The tribe of natives whom we had seen on a previous occasion down this way, having seen the vessel they came to pay us a visit, and crossed the River for that purpose. They were quite peaceable and sat on the bank watching our movements with Astonishment.' ${ }^{99}$ In the afternoon the Aborigines noticed some smoke ascending near Curiosity Peak and moved off in that direction, indicating that they would return later. They 'recrossed the river at the foot of the Dome, each taking a piece of dry wood (of a particularly light Kind of Mangrove) under the arm to buoy them up'. 100

It was probably this river crossing that Wilson elaborated upon in a paper he published in 1858. In it he described how the Aborigines crossed using 'floats ... composed of one, two or three stems, according to their size, of a peculiar kind of mangrove tree, that is, when dead or dry, very light and buoyant'. He went on to describe how a single native would get astride such a float, but if a larger group crossed, as he once saw a 'tribe' including women and children do, they would hang onto the float while swimming alongside. ${ }^{101}$ The fact that Stokes saw rafts and that Wilson saw Aboriginal men, women and children readily cross the river indicates that there was friendly communication and movement between the people on both sides of the stream.

Wilson returned to the depot camp on 14 May and he recorded that on the way he and the men with him, 'dined in the boat at Sandy Island under the scrutinising gaze of a tribe of Natives'. A week or so later Wilson, Elsey and the expedition botanist, Ferdinand Mueller, made another boat trip down river, ${ }^{102}$ and on their return they stopped for breakfast at 'Stony Spit' (below Sandy Island). There they were joined by an Aborigine who had previously provided both Elsey and Mueller with words lists, ${ }^{103}$ and he

\footnotetext{
Wilson and Elsey 1856, entry for 14 April 1856.

98. Wilson and Elsey 1856, entry for 27 April 1856.

99. Wilson 1856, entry for 10 April 1856.

100. Wilson 1856, entry for 10 April 1856.

101. Wilson 1858: 152.

102. Wilson 1856, entry for 21 May 1856.
} 


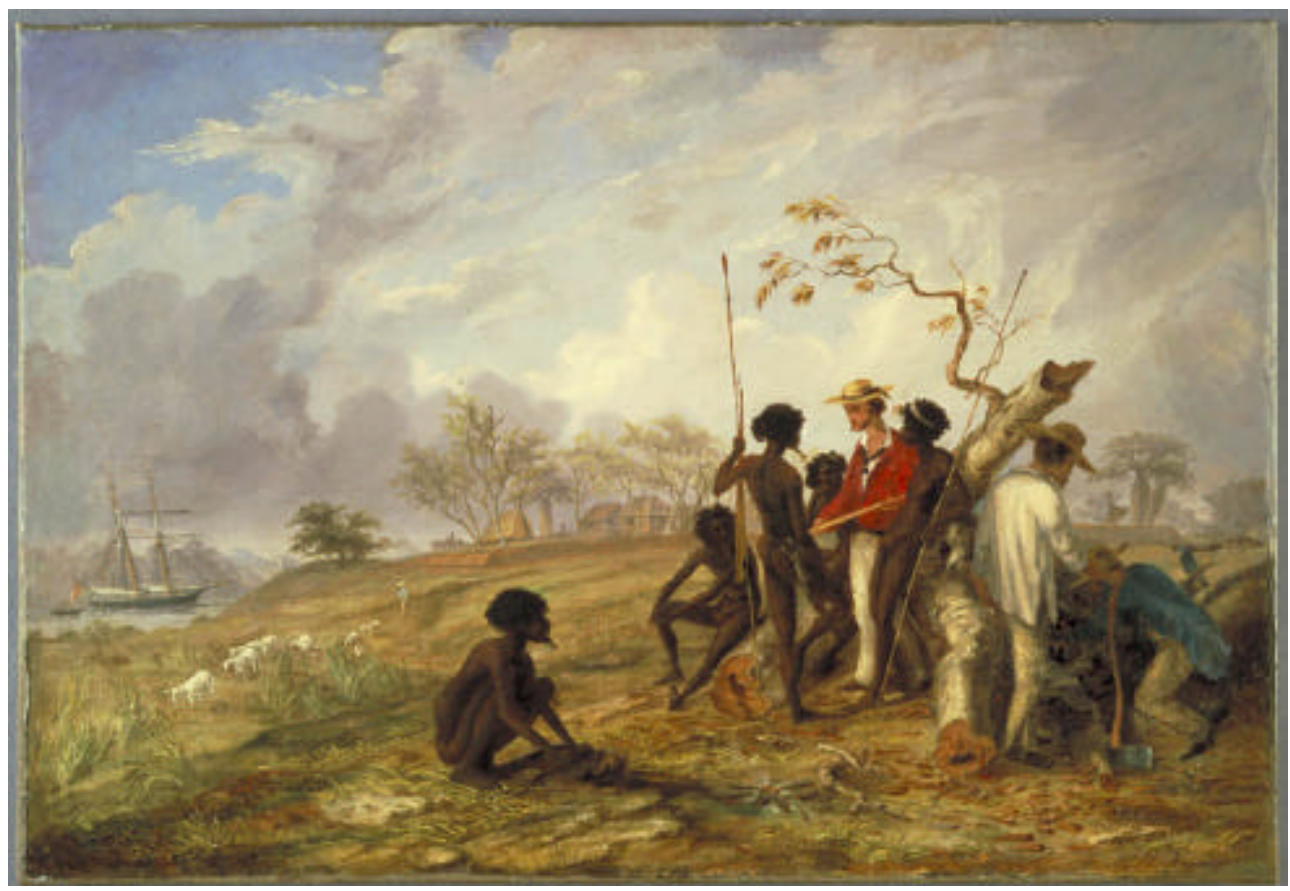

Figure 2: Thomas Baines with Aborigines near the mouth of the Victoria River, NT. 1857. Painting, oil on canvas, 45 x 65.5cm by Thomas Baines. Rex Nan Kivell Collection NK129. National Library of Australia PIC T314 nla.pic an2273869. Shown are Thomas Baines with Aborigines near the depot camp. In the background can be seen the Tom Tough, one of the depot buildings, the mound enclosing the camp and a boab tree.

later went with them in the boat back to the depot. In a paper Wilson published after returning to England, he expanded on this meeting:

We were joined by the old native Deeanna with whom we had already formed a little intimacy. Having given him some bread and tea, he enquired by signs what bread was? In answer I took some seed from a tuft of grass growing by where were sat, and placing it between two stones, rubbed it and showed him the flour; immediately he saw me adopt this operation he expressed satisfaction as though he understood perfectly. 104

The camp journal kept by Wilson and Elsey was discontinued shortly after Gregory's return on 9 May 1856, and for about a month the only record of daily life at the depot is Gregory's journal. During this time Gregory made few mentions of Aborigines. In one instance he noted that a few days after he arrived back, 'a small party of natives came to the camp in the morning and bartered a few trifles, and then retired' ${ }^{105}$ It was probably on this occasion that Thomas Baines made the series of wonderful sketches of Aborigines at the depot camp that are in the Baines collection. ${ }^{106}$

\footnotetext{
103. Wilson 1856, entry for 28 May 1856

104. Wilson 1858: 137-53.

105. Gregory 1981: 151.
} 
One of the last encounters nearly ended badly. On 4 June 1856 in the vicinity of Curiosity Peak, four crewmen from the Tom Tough went on shore to barter with a group of about twenty Aborigines. One of the Aborigines stole a tomahawk from the boat and the Europeans quickly held another captive to secure its return. This led yet another of the Aborigines to try, unsuccessfully, to wrestle a gun from one of the crewmen, whereon all the Aborigines decamped. The tomahawk was found later ${ }^{107}$ and based on the descriptions of the event by those involved, the incident was later recorded in a sketch by Thomas Baines. ${ }^{108}$ Victoria River Aborigines are only mentioned once more in any document from the expedition. When the depot camp was abandoned and the Tom Tough was moving downstream towards the open sea, some Aborigines at Holdfast Reach called out and one ran for some time along the riverbank. ${ }^{109}$ However, the ship soon outpaced them, and the Aborigines on the Victoria were once more left in peace.

After the expedition ended, James Wilson summarised his view of relations between the Aborigines and the explorers on the lower Victoria: 'except on one occasion, our intercourse with them was always amicable, and ... there is no impression left on the minds of the native population unfavourable to their English visitors' ${ }^{110}$ Of course, there were actually a number of mildly unfriendly encounters, but overall this appears to be a fair summation. Sadly, relations between Europeans and Victoria River Aborigines were not to be so friendly and mutually fascinating again for a long time to come.

\section{Summary}

The records of Stokes, Gregory, Thomas Baines, and more particularly of the men permanently stationed at the depot camp, provide an interesting insight into Aboriginal life as it was before being disrupted by the arrival of settlers and cattle. Briefly, we see people who, when confronted with white people for the first time, prudently conceal themselves and observe the strangers from hiding. Remains at their camps show that they were eating turtle, crocodile and mussels. Initially they are probably as fearful of the whites as the whites are of them, but they are also curious. They sneak up for a closer look and in one case they 'test' the strangers with spears. Eventually familiarity brings confidence, and friendly contact is established. Then we see a healthy and confident people. They are naked except for a waist belt of bark or cord, the men bearing body scars, and often with their beard tied in a narrow goatee style and extended with an animal tail. The men carry spears and spearthrowers, stone hatchets and firesticks, and have dingoes as companions.

A seasonal pattern of land use is revealed, with people retreating to major freshwater sources late in the dry season and then spreading out across the land and burning the country at the end of the wet season. We see a large ceremonial gathering during the wet season, a ceremony that we can surmise is an initiation ritual. Patterns of behav-

106. For examples, see Braddon 1986: 68-9; see also the dust jacket and page 83 of Cumpston 1972. The Baines collection is held by the Royal Geographical Society in London.

107. Gregory 1981: 152-53.

108. See Braddon 1986: 77.

109. T Baines, Journal of the Detachment of the North Australian Expedition left by Mr Gregory at the Main Camp Victoria River 1856, entry for July 19 1856. Mitchell Library, C408.

110. Wilson 1858: 137-53. 
iour connected with this ritual - the carrying of a green branch during the ritual approach of one group to another, the control of ritual and by implication the control of knowledge by old people, the separation of women and children from the men for at least part of the ceremony, and the separation of neophytes from 'normal' society, their control and guidance by older men, and their travel into neighbouring areas as part of their education into manhood - are still practiced in the Victoria River region today.

The scarring of the chests and arms of the men indicates the existence of a high stage of initiation, almost certainly the same as or akin to the 'Big Sunday' ceremony carried out in the region today. Finally, we see evidence for the existence of Aboriginal trade and information networks, including the possibility that information about the language, behaviour and skills of white men who until 1849 were stationed at Port Essington, some 600 kilometres to the northeast, was known to Victoria River Aborigines before Gregory's expedition arrived in the district in 1855.

By the time the expedition left the Victoria River, relations between the men at the depot camp and the Aborigines had reached a remarkable state of friendliness. The explorers were indeed 'invaders of a peaceful country', but unfortunately for both sides this experience was not to be repeated for a long time to come. In the 27 years that passed before the arrival of the first settlers, at least 12 private expeditions visited or passed through the region. ${ }^{111}$ Until 1878 these expeditions reported no hostile incidents, but then something changed. We can speculate that the same information networks that may have brought information about the whites at Port Essington had, by 1878 , brought information about the whites along the Overland Telegraph Line and beyond. If so, Victoria River Aborigines may have heard about violent clashes which left many Aborigines dead, and perhaps news that these white men brought large herds of cattle with them and had taken over large areas. ${ }^{112}$

Some Victoria River Aborigines may even have had first hand experience of whites along the line before the first settlers arrived in the Victoria River country. Early settlers' accounts and ethnographic studies reveal that Aborigines in the district travelled long distances outside their own territory for purposes of trade, marriage and ceremony. For example, the early ethnologist RH Mathews learned from the settlers of Aborigines on the upper Victoria River who travelled eastward to Newcastle Waters, then north to Katherine and came back by way of Delamere and Gregory Creek. ${ }^{113}$ At ceremonial gatherings near the telegraph line they would have met Aborigines who had travelled similar distances from different directions, and this situation was repeated from ceremonial gathering to ceremonial gathering, creating 'chains of connection' across most of the continent. These connections enabled people to receive goods and information from regions far beyond their maximum range of travel. ${ }^{114}$ As well as receiving news from Aborigines who may have been in more sustained contact with white people, in the decade before white settlers arrived in the Victoria River district, any Aborigines who made one of these long trips would have seen white people with their own eyes; some may have had negative experiences at their hands.

111. Lewis 2004 chapter 2: 47-84.

112. Lewis 2004 chapters 3 and 4 .

113. Mathews 1901: 69-89.

114. Mulvaney 1976: 72-94. 
Whether some of the Victoria River Aborigines had seen white people along the telegraph line and perhaps experienced rough treatment from them, or whether they had only heard about them, from 1878 they began to resist the intrusions of the landseekers and prospectors, and when the first settlers arrived in 1883 they were met with spears. ${ }^{115}$ Twenty years of open hostility ensued, with at least 15 whites and a considerably greater number of Aborigines being killed or wounded. The settlers became invaders of a violent country, and the peaceful encounters between the Aborigines and Gregory's men on the lower Victoria were forgotten.

\section{References}

\section{Unpublished sources}

Baines, $\mathrm{T}$ 'Journal of the detachment of the North Australian Expedition left by $\mathrm{Mr}$ Gregory at the Main Camp Victoria River 1856', Mitchell Library C408.

Elsey, JR to 'Dear John', dated April 13 1856, National Library of Australia Ms 25/4.

Elsey, JR to his 'beloved parents', nd, National Library of Australia Ms 25/5.

Wickham, JC 'Description of the River Victoria on the N.W. coast of New Holland with directions for approaching it', Mitchell Library A308 (microfilm copy at CY 2627).

Wilson, JS 'Journal by J.S. Wilson, 31 January - 28 May 1856', Mitchell Library ZC 4112 (microfilm copy CY 602).

Wilson, JS and JR Elsey, 'Journal kept at the main camp, Victoria River By J.S. Wilson Geologist and J.R. Elsey Surgeon, to the North Australian Expedition, 1856' [1 January - 9 May 1856], Mitchell Library ZC 411-1 (microfilm copy CY 602).

\section{Secondary sources}

Bennett, MM 1927, Christison of Lammermoor, Alston Rivers, London.

Birdsell, J 1953, 'Some environmental and cultural factors influencing the structuring of Australian Aboriginal populations', American Naturalist 87: 171-207.

Braddon, R, 1986 Thomas Baines and the North Australian Expedition, William Collins, Pty Ltd, Sydney, in association with the Royal Geographical Society.

Buchanan, Bobbie 1997, In the tracks of Old Bluey, Central Queensland University Press, Rockhampton.

Butlin, N 1983, Our original aggression: Aboriginal populations of southeastern Australia 1788-1850, George Allen \& Unwin, Sydney.

Campbell, TD and AJ Lewis 1926, 'The Aborigines of South Australia: anthropometric, descriptive and other observations recorded at Ooldea', Transactions of the Royal Society of South Australia 50: 183-91.

Clendinnen, I 2003, Dancing with strangers, Text Publishing, Melbourne.

Cumpston, J 1972, Augustus Gregory and the Inland Sea, A Roebuck Book, Canberra.

Fenner, FJ 1936, 'Adelaide University field anthropology: central Australia. No. 13 Anthropometric observations on South Australian aborigines of the Diamantina and Cooper Creek regions', Transactions of the Royal Society of South Australia 60.

115. Lewis 2004: 116-17. 
Ferguson, WF 1987, 'Mokare's domain', in Mulvaney, DJ and J Peter White, eds, Australians to 1788, Fairfax, Syme \& Weldon Associates, Sydney: 120-145.

Gregory, AC 1884 [1981], 'North Australian expedition', in Gregory, A and F Gregory. Journals of Australian explorations, facsimile edition, Hesperian Press, Perth.

- 1857, 'North Australian expedition', Journal of the Legislative Council of New South Wales, Session 1856-7, vol 1.

-1858, 'Journal of the North Australian exploring expedition, under the command of Augustus C. Gregory, Esq. (Gold Medallist R.G.S); with report by Mr. Elsey on the health of the party', Journal of the Royal Geographical Society 28.

Harris, J 1985, 'Contact languages at the Northern Territory British military settlements 1824-1849', Aboriginal History 9(2): 148-69.

Hordern, M 1990, 'John Lort Stokes', in Carment, D, R Maynard and A Powell (eds) The Northern Territory dictionary of biography, Northern Territory University Press, Darwin, vol 1: 274-6.

Horton, D (ed) 1994, The Encyclopaedia of Aboriginal Australia, Aboriginal Studies Press, Canberra, vol 2.

Lee, D 1969, 'Variability in human response to arid environments', in McGuinnes, W and B Goldman (eds) Arid lands in perspective, University of Arizona Press, Tuscon: 220-45.

Leichhardt, L 1847, Journal of an overland expedition from Moreton Bay to Port Essington, T \& W Boone, London.

Lewis, D 1990, “"They meet up at Bilinara”: rock art in the Victoria River valley', unpublished MA thesis, Australian National University, Canberra.

- 2004, 'A wild history: the making of Victoria River pastoral society', unpublished PhD thesis, Australian National University, Canberra.

Macquarie Dictionary, 1981, Macquarie Library Pty Ltd, Sydney.

Mathews, RH 1901, 'Ethnological notes on the Aboriginal tribes of the Northern Territory', Queensland Geographical Journal 16: 69-89.

Meggitt, MJ 1974, Desert people, Angus and Robertson, Sydney.

Millik Monmir 1:100,000 map, sheet 4967.

Mulvaney, DJ 1976, “The chain of connection': the material evidence', in N Peterson (ed) Tribes and boundaries in Australia, Social Anthropology Series no. 10, Australian Institute of Aboriginal Studies, Canberra.

-1989, Encounters in place: outsiders and Aboriginal Australians 1601-1985, University of Queensland Press, Brisbane.

Palmer, K 1994, 'Ritual', in D Horton (ed), The encyclopaedia of Aboriginal Australia, Aboriginal Studies Press, Canberra, vol 2.

Peterson, N (ed) 1976, Tribes and boundaries in Australia, Social Anthropology Series no.10, Australian Institute of Aboriginal Studies, Canberra.

Reynolds, H 1981, The other side of the frontier, James Cook University, Townsville.

Reece, B 1990, 'George Windsor Earl', in Carment, D, R Maynard and A Powell (eds) Northern Territory dictionary of biography, vol 1: to 1945, Northern Territory University Press, Darwin.

Rose, D 1992, Dingo makes us human, Cambridge University Press, Melbourne. 
Spillett, P 1972, Forsaken settlement: an illustrated history of the settlement of Victoria, Port Essington north Australia 1838-1849, Lansdowne Press, Sydney.

Stirling, E 1966, Report on the work of the Horn Scientific Expedition to central Australia. Part $I V$, Mullen and Slade, Melbourne.

Stokes, JL 1969, Discoveries in Australia, State Library of South Australia, facsimile edition, vol 2 (originally published by T \& W Boone, London, 1846).

Tindale, N 1974, Aboriginal tribes of Australia, Australian National University Press, Canberra.

Victoria River 1:100,000 map, sheet 4867.

Wells, S 2003, 'Negotiating place in colonial Darwin: interactions between Aborigines and Whites 1869-1911', unpublished PhD thesis, University of Technology, Sydney.

Wilson, JS 1858, 'Notes on the physical geography of north-west Australia', Journal of the Geographical Society of London 28. 